\title{
MORPHOLOGY AND SEXUAL DIMORPHISM OF THE MANY-LINED SKINK IN NORTH CENTRAL NEW MEXICO
}

\author{
Charles D. Hathcock ${ }^{1,2,4}$, Marjorie A. Wright ${ }^{1,2}$, \\ Donald S. Sias ${ }^{3}$, and Gilbert J. Gonzales ${ }^{1}$
}

\begin{abstract}
AвstraCt.-In 2001 and 2002, a study of many-lined skinks (Plestiodon multivirgatus) was conducted by Los Alamos National Laboratory biologists in north-central New Mexico to determine means and ranges for several morphological characters and to test for sexual dimorphism. Over both years, there were 539 new captures of many-lined skinks, which included 131 hatchlings. The earliest hatchling capture was on 19 June and the latest capture was on 31 August. Hatchling captures peaked on 1 August in 2001 and 6 August in 2002. The age class, sex, snout-vent length (SVL), tail length (TL), mass, head length (HL), and head width (HW) were recorded and individuals were released at the point of capture. Our results indicate that the SVL, mass, HL, and HW did not exhibit sexual dimorphism. The sex ratio was skewed toward females in this study. It is not known whether the many-lined skink has sexual determination based on environmental factors, but the data here suggest that more research is needed. From these observations, we supplement the limited existing knowledge on the morphology of this species.
\end{abstract}

Resumen.-Un estudio del scincido (Plestiodon multivirgatus) se llevó a cabo por biólogos del Laboratorio Nacional de Los Álamos (LANL) en el norte-centro de Nuevo México, en 2001 y 2002, para determinar las medias y los rangos de diversos caracteres morfológicos y para estudiar el dimorfismo sexual. Durante estos dos años, se capturaron 539 nuevos individuos que incluyeron 131 crías. La primera captura de crías fue el 19 de junio y la última el 31 de agosto. Las capturas de crías alcanzaron su punto máximo el 1 de agosto del 2001 y el 6 de agosto del 2002. Se registró el grupo de edad, sexo, longitud hocico-cloaca (SVL), longitud de la cola (TL), masa, longitud de la cabeza (HL) y el ancho de la cabeza $(\mathrm{HW})$ y posteriormente los individuos fueron liberados en el mismo lugar de su captura. Nuestros resultados indican que el SVL, la masa, HL, y HW no son sexualmente dimórficos. La proporción de sexos estuvo sesgada hacia las hembras. No se sabe si esta especie tiene su determinación sexual en base a factores ambientales, pero los datos de este trabajo sugieren que se necesitan más investigaciones. A partir de estas observaciones ampliamos el conocimiento limitado existente sobre la morfología de esta especie.

The many-lined skink (Plestiodon multivirgatus) occurs from the southern edge of North Dakota southward, through the southeastern corner of Wyoming, through central Colorado, throughout much of New Mexico (NM), and the northeastern corner of Arizona (Stebbins 2003). In north central NM the species can be found at high elevations up to $2575 \mathrm{~m}$ (Degenhardt et al. 1996). This medium-sized skink has 2 color patterns-a striped and a stripeless phase. Generally these lizards are found in mesic habitats but are occasionally found in rocky talus slopes in open pine woodlands in northern and western NM (Degenhardt et al. 1996).

During the summers of 2001 and 2002, we monitored 4 canyons for many-lined skinks. Two canyons (Sandia and DP canyons) were in Los Alamos County on Los Alamos National Laboratory (LANL) property, and 2 canyons
(Garcia and Chupaderos canyons) were in Rio Arriba County on lands formerly owned by the Santa Fe National Forest. The purpose of the study was to determine means and ranges for several morphological characters and to test for sexual dimorphism.

\section{METHODS}

The LANL is located in Los Alamos County, in north central NM, approximately $100 \mathrm{~km}$ north-northeast of Albuquerque. The 10,240-ha LANL site is situated on the Pajarito Plateau. Sandia and DP canyons are located within LANL and are dominated by a riparian community with perennial water flows. This habitat consists primarily of narrowleaf cottonwood (Popu lus angustifolia James), narrowleaf willow (Salix exigua Nutt.), Gambel oak (Quercus gambelii

\footnotetext{
${ }^{1}$ Los Alamos National Laboratory, Environmental Stewardship, Los Alamos, NM 87545.

2Present address: Los Alamos National Laboratory, Box 1663, Mailstop J978, Los Alamos, NM 87545

${ }^{3}$ Private Consultant, Don S. Sias, 307 San Lorenzo Ave. NW, Albuquerque, NM 87107.

${ }^{4}$ Corresponding author. E-mail: hathcock@lanl.gov
} 
TABLE 1. Morphological measurements of adult manylined skinks collected during 2001 and 2002 in north central New Mexico. $\mathrm{N}=$ Length and width measurements are given in millimeters.

\begin{tabular}{|c|c|c|}
\hline & Females & Males \\
\hline \multicolumn{3}{|c|}{ THIS STUDY } \\
\hline \multicolumn{3}{|c|}{ Snout-vent length } \\
\hline$n$ & 187 & 82 \\
\hline $\bar{x}$ & 61.60 & 61.95 \\
\hline SE & 0.32 & 0.58 \\
\hline Range & $50.84-77.46$ & $50.55-71.77$ \\
\hline \multicolumn{3}{|l|}{ Mass (g) } \\
\hline$n$ & 186 & 82 \\
\hline $\bar{x}$ & 4.25 & 4.52 \\
\hline SE & 0.07 & 0.13 \\
\hline Range & $1.98-7.65$ & $2.5-7.88$ \\
\hline \multicolumn{3}{|c|}{ Tail length } \\
\hline$n$ & 41 & 14 \\
\hline $\bar{x}$ & 89.47 & 90.05 \\
\hline SE & 2.61 & 2.08 \\
\hline Range & $34.21-115.43$ & $70.68-100.61$ \\
\hline \multicolumn{3}{|c|}{ Head length } \\
\hline$n$ & 32 & 39 \\
\hline $\bar{x}$ & 11.32 & 11.32 \\
\hline SE & 0.12 & 0.14 \\
\hline Range & $9.73-12.41$ & $9.26-12.65$ \\
\hline \multicolumn{3}{|c|}{ Head width } \\
\hline$n$ & 32 & 39 \\
\hline $\bar{x}$ & 8.00 & 8.28 \\
\hline $\mathrm{SE}$ & 0.10 & 0.11 \\
\hline Range & $6.73-9.26$ & $7.07-9.95$ \\
\hline \multicolumn{3}{|c|}{ GEHLBACH 1965} \\
\hline \multicolumn{3}{|c|}{ Snout-vent length } \\
\hline$n$ & 11 & 12 \\
\hline $\bar{x}$ & 65.5 & 55.6 \\
\hline Range & $49-70$ & $42-68$ \\
\hline
\end{tabular}

Nutt.), and broadleaf cattail (Typha latifolia L.). Garcia and Chupaderos canyons are located in Rio Arriba County approximately $10 \mathrm{~km}$ north of LANL. These canyons have intermittent flows and a similar riparian community. We chose the 4 sites because they contained similar habitats with similar elevation and aspect, but occurred in different counties. This added variation to the data and captured a broader subset of the overall population in this region.

In each canyon, we established two 200-m transects, one on either side of the stream channel. We installed 10 pitfall trap arrays along each transect using paired 3.8-L buckets on both ends of a metal flashing drift fence. Each canyon contained 68 total pitfalls.

During June-September 2001 and MayAugust 2002, we opened traps every Monday morning, checked them daily during the week, and closed them on Friday afternoon. We measured captured skinks and gave them a unique mark by injecting plastic elastomers (Northwest
Marine Technology, Inc., Shaw Island, WA, USA) in the inguinal and axial regions of the skink's vent. Elastomers have been used in small reptiles in past studies (Penney et al. 2001, Schmidt and Schwarzkopf 2010) but were not successful in this study. The recaptures were not reliably identified by their unique marking on account of the migration of the plastic elastomer under the skin and fading into the skin. Because of this, we do not report recaptures herein.

We recorded the age class, sex, snout-vent length (SVL), tail length (TL), mass, head length (HL), and head width (HW) and released individuals at the point of capture. We determined sex using cloacal probes. We used NCSS 9.0 (Hintze 2013) to analyze data. Data were tested for normality using Kolmogorov-Smirnov tests. We conducted an analysis of variance (ANOVA) to compare the SVL between sexes. We conducted analyses of covariance (ANCOVAs) to compare mass, HL, and HW between sexes and to test for interactions between sex and SVL (used as a covariate). We removed hatchlings from these analyses. Descriptive statistics are presented as $\bar{x} \pm \mathrm{SE}$ and range, and the significance level was set at $\alpha=0.05$.

\section{RESUlTS}

The overall range of the SVL measured in adult females was 50.84-77.46 $\mathrm{mm}(\bar{x}=61.60$ $\pm 0.32 \mathrm{~mm}, n=187)$ and in adult males was $61.95-71.77 \mathrm{~mm}(\bar{x}=61.95 \pm 0.58 \mathrm{~mm}, n=82$; Table 1). The ANOVA indicated no significant difference in SVL between sexes $\left(F_{1,273}=0.70\right.$, $P=0.40)$.

The overall range of the mass measured in adult females was $1.98-7.65 \mathrm{~g}(\bar{x}=4.25 \pm$ $0.07 \mathrm{~g}, n=186)$ and in adult males was 2.50 $7.88 \mathrm{~g}(\bar{x}=4.52 \pm 0.13 \mathrm{~g}, n=82$; Table 1$)$. The ANCOVA on mass, controlling for SVL, indicated no significant difference between sexes $\left(F_{1,270}=1.74, P=0.18\right)$ and no significant interaction between sex and SVL $\left(F_{1,270}=2.23\right.$, $P=0.13)$.

The HL and HW were only collected in the second year of the study in adult skinks. The overall range of HL in adult females was 9.73-12.41 mm ( $\bar{x}=11.32 \pm 0.12 \mathrm{~mm}, n=32)$ and in males was $9.26-12.65 \mathrm{~mm}(\bar{x}=11.32 \pm$ $0.14 \mathrm{~mm}, n=39$; Table 1 ). The ANCOVA on HL, controlling for SVL, indicated no significant difference between sexes $\left(F_{1,66}=0.32\right.$, 
$P=0.57)$ and no significant interaction between sex and SVL $\left(F_{1,66}=0.46, P=0.49\right)$.

The overall range of $\mathrm{HW}$ in adult females was $6.73-9.26 \mathrm{~mm}(\bar{x}=8.00 \pm 0.10, n=32)$ and in males was $7.07-9.95 \mathrm{~mm}(\bar{x}=8.28 \pm$ $0.11 \mathrm{~mm}, n=39$; Table 1). The ANCOVA on $\mathrm{HW}$, controlling for SVL, indicated no significant difference between sexes $\left(F_{1,66}=1.29\right.$, $P=0.26)$ and no significant interaction between sex and SVL $\left(F_{1,66}=0.74, P=0.39\right)$.

Tail lengths reported are for complete original tails only (i.e., data for individuals with tail breaks or tail break scars were not included). The overall range of the TL in adult females was $34.21-115.43 \mathrm{~mm}(\bar{x}=89.47 \pm 2.61 \mathrm{~mm}$, $n=41)$ and in males was $70.68-100.61 \mathrm{~mm}(\bar{x}$ $=90.05 \pm 2.08 \mathrm{~mm}, n=14$; Table 1 ). The tail lengths were not analyzed for dimorphism because the majority of the tails were broken.

For both years over all 4 canyons, there were 131 new hatchlings captured. The earliest capture was on 19 June and the latest capture was on 31 August. Hatchling captures peaked on 1 August in 2001 and 6 August in 2002. The range of SVL in hatchlings was $24.27-43.82 \mathrm{~mm}$ $(\bar{x}=30.18 \pm 0.29 \mathrm{~mm}, n=131)$ and mass was $0.23-1.0 \mathrm{~g}(\bar{x}=0.49 \pm 0.01 \mathrm{~g}, n=131)$.

\section{Discussion}

Sexual dimorphism in lizards is commonly reported in the literature (Vitt and Cooper 1985, Cooper and Vitt 1989, Andersson 1994, Olsson et al. 2002), but studies of the many-lined skink are few. Although many lizard species are sexually dimorphic in one way or another (Pianka and Vitt 2003), results from this study (SVL, mass, HL, and HW) do not support sexual size dimorphism in this species.

The mean SVLs reported in Gehlbach (1965) were larger $(>4 \mathrm{~mm})$ in females and smaller $(<6 \mathrm{~mm})$ in males than those reported in this study (Table 1). The findings in Gehlbach (1965) were based on 11 female and 12 male specimens collected in the Zuni Mountains in McKinley and Cibola counties, NM. The larger sample size in this study explains more variation in the species. Mecham (1980) reports that the average SVL of adult many-lined skinks was $65 \mathrm{~mm}$, with a maximum of $73 \mathrm{~mm}$, but the sample size was not reported.

The sex ratio was skewed toward females in this study by more than 2 to 1 . Reptiles possess a wide variety of sex-determining mechanisms, more so than any other vertebrate group (Wapstra and Warner 2010); however, temperaturedependent sex determination (TDSD) in lizards is poorly understood (Valenzuela et al. 2003). Inamdar et al. (2012) reported that temperature had a significant effect on sex ratios in an oviparous lizard, whereas Hare and Daugherty (2002) reported that equal sex ratios were found at all incubation temperature regimes in a New Zealand skink. Although TDSD provides a potential explanation for female-biased sex ratios in this study, it is not known whether this species exhibits TDSD, so other possibilities cannot be dismissed (such as sampling bias, intersexual differences in mortality or migration rates, or other environmental factors).

These observations represent a robust assessment of the morphology of the many-lined skink in northcentral NM and provide valuable information about the natural history of the species.

\section{ACKNOWLEDGMENTS}

We thank D. Keller, D. Lujan, B. Pearson, L. Sandoval, R. Velasquez, J. Vencil, and G. Vigil for field support during this project. We thank T. Hibbitts, C. Painter, D. Leavitt, L. Hansen, and G. Carpenter for helpful comments on this manuscript. This project was operated under an approved Institutional Animal Care and Use Committee protocol, and this research was funded by the Environmental Protection Program through Los Alamos National Security, LLC, operator of the Los Alamos National Laboratory under Contract DE-AC52-06NA25396 for the National Nuclear Security Administration of the U.S. Department of Energy.

\section{Literature Cited}

Andersson, M. 1994. Sexual selection. Princeton University Press, Princeton, NJ. 624 pp.

Cooper, W.E., JR., AND L.J. VitT. 1989. Sexual dimorphism of head and body size in an iguanid lizard: paradoxical results. American Naturalist 133: 729-735.

Degenhardt, W.G., C.W. Painter, and A.H. Price. 1996. Amphibians and reptiles of New Mexico. University of New Mexico Press, Albuquerque, NM.

Gehlbach, F.R. 1965. Herpetology of the Zuni Mountains region, northwestern New Mexico. Proceedings of the U.S. National Museum 116:243-332.

HaRe, K.M., AND C.H. Daugherty. 2002. Incubation regime affects juvenile morphology and hatching success, but not sex, of the oviparous lizard Oligosoma suteri (Lacertilia: Scinidae). New Zealand Journal of Zoology 29:221-229. 
Hintze, J. 2013. NCSS 9. NCSS, LLC, Kaysville, UT. www.ncss.com

Inamdar (Doddamani), L.S., V. Vani, And P.B. Seshagiri. 2012. A tropical oviparous lizard, Calotes versicolor exhibiting a potentially novel FMFM pattern of temperature-dependent sex determination. Journal of Experimental Zoology 317:32-46.

Mecham, J.S. 1980. Eumeces multivirgatus. Catalog of American Amphibians and Reptiles 241:1-2.

Olsson, M., R. Shine, E. Wapstra, B. Ujvari, and T. Madsen. 2002. Sexual dimorphism in lizard body shape: the roles of sexual selection and fecundity selection. Evolution 56:1538-1542.

Penney, K.M., K.D. Gianopulos, E.D. McCoy, and H.R. MUSHINSKY. 2001. The visible implant elastomer marking technique in use for small reptiles. Herpetological Review 32:236-241.

Pianka, E.R., and L.J. VitT. 2003. Lizards: windows to the evolution of diversity. University of California Press, Los Angeles, CA.

Schmidt, K., AND L. Schwarzkopf. 2010. Visible implant elastomer tagging and toe-clipping: effects of marking on locomotor performance of frogs and skinks. Herpetological Journal 20:99-105.

Stebbins, R.C. 2003. A field guide to western reptiles and amphibians. 3rd edition. Houghton Mifflin Company, Boston, MA.

Valenzuela, N., D.C. Adams, and F.J. Janzen. 2003. Pattern does not equal process: exactly when is sex environmentally determined? American Naturalist 161:676-683.

ViTT, L., AND W.E. CoOper JR. 1985. The evolution of sexual dimorphism in the skink Eumeces laticeps: an example of sexual selection. Canadian Journal of Zoology 63: 995-1002

WaPSTRA, E., AND D.A. WARNER. 2010. Sex allocation and sex determination in squamate reptiles. Sexual Development 4:110-118.

Received 25 March 2014 Accepted 2 March 2015 